\title{
У ЗНАКУ ПЕЋКЕ ПАТРИЈАРШИЈЕ. НЕКОЛИКО РЕЧИ О СТАРОЈ СРПСКОЈ КУЛТУРИ**
}

\begin{abstract}
У раду се разматра проблем обновљене Пећке патријаршије и њено значење, утицај на све области како црквене, тако и културне, књижевне и уметничке делатности. У ширем контексту представљају се најважнији, суштински елементи овог изванредног и непролазног пројекта. Дакле, посебна пажња се обраћа како на феномен обнове српске Цркве, тако на њен историјски, политичко-еклезијални, културни и друштвени значај у контексту службе српске традиције и колективног памћења. У односу на обнову Пећке патријаршије сигнализира се у главним цртама такође проблем времена, традиције, памћења, узајамних веза прошлости и савременог тренутка у простору старе српске културе.

Кључне речи: Пећка патријаршија, обнова, турско доба, српска традиција, култура, друштво, модел, идентитет, припадност, прошлост, памћење.
\end{abstract}

Разматрајући проблем Пећке патријаршије, њене обнове 1557. године у односу на културу (на стару српску културу, па књижевност, уметност, архитектуру итд), треба, између осталог, истаћи питање традиције и памћења, њихове својеврсне функционализације у служби непроменљивости културно-друштвеног модела. Уз то треба и подвући њихове узајамне везе, ваља макар у општим цртама обратити пажњу на суштину и функцију ове повезаности. Обично се она примећује у таквом културном систему који се може дефинисати као специфично затворен, компактан, херметичан или просто редукционистички и хладан; који се - по меморијалној концепцији Јана Асмана - може одређивати као „митомоторички” осетљив. ${ }^{1}$ Дакле, говори се овде о култури памћења за коју је карактеристично почетно својеврсно неговање - записивање - обележавање традиције, важних и изабраних, вредних памћења личности, догађаја, чињеница; а затим посебно реконструисање и

\footnotetext{
*izalisek@go2.pl

** Овај чланак треба да се третира као део једног ширег ауторског концепта - циклуса радова посвећених старој српској култури као меморијалном систему.

${ }^{1}$ Види: Асман 2011.
} 
идеализовање славне, херојске прошлости, актуализовање тзв. фундирајућих нарација, чување и учвршћивање „харизматичних догађаја” сасвим природно и релативно брзо преображених у митове који заједно творе неку количину „харизматичне историје”. У светлу тога говори се такође о самом односу према прошлости који је - како наглашава Ј. Асман - „у служби двеју наоко супротстављених функција”, од којих се прва назива „фундирајућом”, друга „контрапрезентном” (Асман 2011: 79-80). Ова прва „ставља садашњост под светлост једне историје која допушта да она буде смислена, по жељи богова [Бога - I. L.W.], нужна и неизбежна”, а друга „полази од недовољног (дефицијентног) искуства садашњости и у сећању призива прошлост која најчешће поприма карактер херојских времена" (Асман 2011: 79-80). Важно је подвући да према Ј. Асману „појмови фундирано и контрапрезентно нису својствени неком миту као таквом, него значењу које он има за неку садашњост приликом формирања слике о себи и стварања модела делања, као и усмеравајућој снази коју он поседује за неку групу у одређеној ситуацији", стога се и у студији немачког истраживача ова снага назива „митомоториком" (Асман 2011: 80-81).

Дакле, може се рећи да овде предложене чак и укорењене у научном меморијалном дискурсу, шире у оквиру тзв. memory studies, категорије и функције или опције јако добро служе опису ових културних система који су изузетно карактеристични - компактни и херметични, специфично затворени и хладни, будући да чувају неприкосновеност традиције, који су отпорни на промене или просто способни да ,замрзну” промене, потенцијално неповољне за трајност културно-друштвеног модела (Асман 2011: 79-80). Наравно, говори се о системима који очигледно испољавају својеврсну меморијалну осетљивост, митомоторички потенцијал. Управо један од таквих система јесте стара српска култура која се може успешно одређивати помоћу појмова, категорија својствених такозваној култури памћења. Да би се баш тако могло говорити о старој српској култури (књижевности, уметности, архитектури и др), треба да се нагласи њена дуготрајност, континуитет и компактност у двема - овде предложеним - развојним фазама са својеврсном цензуром између пада деспотовине 1459. године и обнове Пећке патријаршије 1557. године; а у томе пре свега ваља да се подвуче њена знатна отпорност која се схвата баш у односу на „фундирајућу” и „контрапрезентну” функцију. Обично је, као што је речено, ова прва карактеристична пре свега за тзв. хладне културе и друштва. У случају старе српске културе она би додуше била приметна у обадва периода, с тим што би се она као доминантна огледала у време трију династичких родова - Немањића, Лазаревића, Бранковића. Тада је она присутна у шире схваћеној културној делатности - како у књижевности у области великих жанрова (хагиографским, химнографским, историографским, епистолографским деловима), а такође у кратким књижевним формама (записима); тако и у иконографским, архитектонским и другим уметничким реализацијама. Обе су функције - „фундирајућа” и „контрапрезентна” - карактеристичне и за сву културну активност у овде условно схваћеној другој фази развитка старе српске културе. Ипак, може се рећи да је онда опција 
„контрапрезентности” некако супериорна. Очигледно, ове две функције не морају се међусобно искључивати, исто тако културе и друштва не морају бити скроз „хладне” или „вруће”, јер се у сваком систему могу препознавати и хладни и врући елементи (Асман 2011: 70). Тако је и у случају старе српске културе, нарочито у периоду обновљене Пећке патријаршије, мада треба да се нагласи и њен ипак стално доминантан хладан и - према Јовану Деретићу - редукционистички карактер (Деретић 2000: 63). Уз то ваља обратити посебну пажњу на својеврсно „отопљење”, које је онда у сећању наступило заједно са процесом појачавања колективне свести услед институционалног деловања (шире активности обновљене Пећке патријаршије) и уједно функционисања у стању дуготрајне опасности (животу у турском ропству). Таква ситуација може се још боље схватити у односу на Асманове речи о митомоторичком преображавању идеје / визије / концепта, када он о „контрапрезентној” опцији пише следеће: „У екстремним искуставима дефицијенције, под условима стране владавине и угњетавања, контрапрезентна митомоторика може постати револуционарна. Тада предања не потврђују дато стање, већ их доводе у питање и позивају на мењање тог стања и на преврат. Прошлост на коју се односе не појављује се као непоновљиво херојско доба, већ као нека политичка и социјална утопија за чије се остварење вреди борити и живети /.../ Да бисмо илустровали овај облик митомоторике, не морамо се враћати у далеку прошлост. Сви национални покрети буђења свести мобилизују сећање на неку прошлост која стоји у директној супротности спрам садашњости и која постаје жељено стање које треба створити, стање слободе и самоопредељења, за које се мора скинути 'јарам стране власти'” (Асман 2011: 81-84). Отуда се може рећи да се у периоду тзв. друге патријаршије „фундирано” очито преокреће у „контрапрезентно”, што не значи потпуну промену јер у ондашњој српској култури ипак стално преовлађује хладна димензија памћења; ваља подсетити да по Клоду Леви-Стросу „хладна друштва су она која теже да уз помоћ 'снаге институција, на такорећи аутоматски начин избришу последице историјских фактора на њихову равнотежу и њихов континуитет"” (Асман 2011: 68).

У односу на овде сигнализиране категорије, функције или опције које припадају ширем дискурсу тзв. memory studies, може се у неку руку сагледати стара српска култура као целина. Штавише, због њеног меморијалног карактера, очигледне политике памћења коју су почетно водиле држава и Црква, а доцније само Пећка патријаршија као једина српска институција, могу да се изнесу и основне компоненте ове стратегије, тј. елементи који су подлежни одређеној функционализацији и који су одговорни за хладан и трајан облик културног и друштвеног памћења. Наравно, ствар је пре свега о фундаменталном односу према прошлости, о специфичној стратегији - политици деловања у датој (тадашњој) садашњости, о својеврсном императиву овековечивања историје (садашње а пре свега прошле) путем идеологизације, митологизације, сакрализације, а најзад хероизације која је нека количина свих ових поменутих културних процедура које одређују оријентацију и идентитет српске културе и заједнице, испољавају управо њихов митомо- 
торички потенцијал. Дакле, у великој мери ради се баш о феномену хероизације који се у неку руку може третирати као референција старог српског система културе. Да би се овај феномен добро разумео, мора да се разматра у бар неколико контекста, на неколико нивоа или стаза испитивања, од којих се најважнији чини - културни модел који је у том случају изразито карактеристична, кохерентна и херметична структура.

Разматран средњовековни модел српске културе који се сматра узорком, формирао се у доба трију династија - Немањића, Лазаревића и Бранковића. Он је, додуше, као такав постојао и функционисао у периоду од 12. до 15. столећа, али се ипак његово датирање не поклапа са временом постојања српскога средњовековља, чији се крај може видети тек у половини 18. столећа. ${ }^{2}$ Без обзира на понекад још дискутабилан проблем трајања, датирања, опште периодизације, који се тиче углавном српске књижевности, треба ипак подвући дуготрајност старог српског културног модела, његов развитак и постојање у двема фазама које су биле пре свега детерминисане историјским, политичким, еклезијалним и другим догађајима. Прва би се могла назвати стварном, када се уопште културни модел формирао и када је реч о стратегији „фундирајућег” овековечавања традиције. Она би трајала све до пада српске деспотовине. Међутим, друга фаза, од обнове Пећке патријаршије, могла би се именовати симболичном или просто меморијалном, када се културни модел јавља већ као облигаторна полазна тачка, када он подлеже перманентној реконструкцији, актуализацији, кодификацији и локацији већ у регистру културног памћења. Ваља нагласити да се обе фазе не морају сасвим одвајати, јер - како каже Дорота Гил - већ у време српске деспотовине и уопште у турско доба уочљиви су процеси неговања раније сатворене традиције и допуњавања новим идеолошким елементима, а може се и рећи меморијалним састојцима. ${ }^{3}$ Отуда произилази и закључак да је реч о својеврсном континуитету културног модела и традиције, и поред тога што је тада ипак наступио прекид државне историје, а Црква у том тренутку није нормално функционисала. Управо у том прелазном времену треба тражити почетке обликовања и кодификације, најзад и сећања одређене - идеалне визије прошлости (утврђивања старог српског модела културе у категоријама узорка), што се у програму обновљене Пећке патријаршије чини надређеном сврхом, главном компонентом њеног целокупног пројекта. Упркос историјском прекидању државно-црквеног континуитета, трајност културно-друштвене традиције је сачувана, што се може разумети у односу на механизам „контрапрезентности”. Мартин Кула, разматрајући проблем културно-друштвеног памћења и заборављања, каже да „прекидање традиције, нарочито нагло, понекад је повољно за сачување сећања на стара времена, просто за њихову петрификацију, сакрализацију” (Кула 2004: 163), а може се и рећи меморијализацију.

Дакле, у том контексту опште питање обнове Пећке патријаршије веома је важно, оно је просто кључно и неопходно за целокупно читање старе срп-

\footnotetext{
${ }^{2}$ Види Lis-Wielgosz 2013: 15-28.

${ }^{3}$ Види Gil 2005: 47.
} 
ске културе. Додуше, у науци оно је било већ више пута расправљано, због тога чини се да нема разлога да се понављају одавно познате дефиниције, концепције, подаци. Исто тако не треба да се подробно описују све области како црквене, политичке, друштвене, тако и културне, књижевне и уметничке делатности под окриљем тзв. друге патријаршије. Ипак, треба представити бар најважније, суштинске елементе и димензије овог изванредног и непролазног институционалног пројекта, који се у неку руку може сматрати и као компактно-меморијални програм.

Ваља подвући да се обнова патријаршије показала као преломни моменат у историји српске заједнице, пре свега она је била од великог значаја за културно-друштвени модел. Са једне стране, она је била ново отварање, време релативно коректних и мирних односа са турском влашћу ${ }^{4}$, са друге стране, донела је неку врсту трансформације система чији је темељ до тада била идеја дијархије, формула истовремено постојећих, функционишућих у узајамној симфонији двеју власти - црквене и државне. Може се рећи да је промена у том оквиру изазвала и неко померање других системских елемената, и поред тога није ипак дошло до кршења културне структуре као целине. ${ }^{5}$ Српска православна црква као битан фактор који је формирао српско осећање цивилизацијске припадности и етноконфесионалан идентитет (чији је темељ светосавски хоризонт значаја) ${ }^{6}$, у турско време била је једина постојећа институција која је нарочито чувала - како каже Дорота Гил - оно што је у колективној свести укоренио Свети Сава, тј. уверење о изузетности историје српске државе и народа. ${ }^{7}$ Сличног мишљења је Станоје Станојевић, који истиче да је управо обновљена Пећка патријаршија у тешким историјско-политичким и еклезијалним околностима успоставила, оживела црквенодржавну традицију, чиме је у неку руку вратила српској заједници осећање достојанства и вредности, учврстила српски идентитет, колективну историјску свест и културно памћење (Станојевић 1926: 253-256). Дакле, Пећка патријаршија се показала као центар подржавања и ревитализације онога што је Питрим Сорокин назвао ,аспектом значења” који спаја сваки културнодруштвени систем. ${ }^{8}$ Српски систем сразмерно брзо је почео функционисати у облику специфичне културе памћења која се концентрисала око свог јединог институционалног центра - патријаршије која је била знак и уједно место памћења старе српске традиције и културно-друштвеног модела.

Обновљена Пећка патријаршија обухватила је тада велики простор, етнички српске покрајине, о чему Станоје Станојевић каже да су онда „после много векова, Срби у Босни и у старој Рашкој, и Срби на Моришу и на Вардару, на Тимоку, Морави и у приморју опет осетили да су спојени, али не само у државној заједници, која је била туђа и која их је све подједнако тиштала,

\footnotetext{
${ }^{4}$ Види Слијепчевић 1978: 301; Ћоровић 1929: 265.

${ }_{5}^{5}$ Овде је реч о могућности описа померања неких елемената система који је истовремено непомерљив као целина; види нпр. Леви-Строс 1989; Piaget 1968.

${ }^{6}$ Види Деретић 2005: 125.

${ }^{7}$ Види Gil 2005: 27.

${ }^{8}$ Види Sorokin 1941: 93.
} 
него и у заједници, која је била њихова рођена, у једној организацији, која је радила и бринула се за њих и пружала им духовне хране, наде и утехе". Ваља подвући да је на тај начин, јурисдикцијски, патријаршија знатно прекорачила старе границе српске архиепископије из Немањићког периода. ${ }^{10}$ Треба нагласити да се у сфери њеног утицаја и под њеном влашћу нашло не само српско него и бугарско, влашко, молдавско, далматинско и друго становништво, које је стварало својеврсну мултиетничку, а пре свега верску и културну заједницу. Ово је изванредан и уједно редак феномен, који се у науци није сувише често разматрао, јер се обично истицало значење обнове једино за православне Србе. Овде треба истаћи и уједно подсетити да није био у праву Јован Деретић када је о границама, положају тзв. друге патријаршије и њеног становништва, писао да „њене границе нису биле повучене ни по политичким ни по верским, него по етничким линијама. За православце унутар тих граница сматрало се тада да су Срби и они су сами тако осећали. Другим разлозима те границе се не могу објаснити” (Деретић 2005: 125). Чини се да основа таквог мишљења може потицати из сувише претераног излагања процеса дубоке „етнизације религије”. Ваљда је истинито представљање Пећке патријаршије као институције која је онда обухватила скоро цео српски народ, чиме је и сама некако експонирала етнонационални профил ове заједнице. ${ }^{11}$ И поред тога треба узети у обзир да је на Балкану - како правилно наглашава Милорад Екмечић - од продора Турака, вера (хришћанска православна) постала кључна одредница идентитета, понекад важнија од језика или етничког порекла. ${ }^{12}$ И поред тога, ваља пристати на чињеницу да су ондашње границе српске патријаршије биле изузетна појава, што је и подвукао сам Јован Деретић у констатацији да „ниједна српска политичка институција ни пре ни после тога није тако потпуно обухватила цео српски народ као што је то учинила Пећка патријаршија. Парадокс је да су Срби у тренутку када су изгубили све елементе државности, постигли политичко јединство какво никад нису имали. Наравно, то јединство било је мањкаво. Српска заједница постала је етноконфесионална, из ње су аутоматски испали сви они Срби који нису били припадници СПЦ, који су пригрлили другу веру. Црква је тако постала не само духовна него и политичка институција српског народа, наследница средњовековне државе и чувар њених традиција. Она је истовремено била политичка форма опстанка српског народа под турском влашћу" (Деретић 2005: 125).

Обнова Пећке патријаршије може се разматрати на различитим нивоима, а њена посебна вредност тражити и описивати у историјској, политичкој, еклезијалној, друштвеној, а такође културној перспективи. Ова вишедимензионална реституција је била од великог значаја и за српску културу и уметност; може се рећи да је у неку руку обнова синоним препорода, који Јован Деретић просто сматра „малом националном ренесансом, која се осетила у

\footnotetext{
${ }^{9}$ Станојевић 1993/1926: 256; Лис-Вјелгош 2019: 237-248.

${ }^{10}$ Види Чубриловић 1960: 174.

${ }^{11}$ Види нпр. Станојевић 1993/1926: 256; Веселиновић 1937: 289, 293; Екмечић 2008.

${ }^{12}$ Види Екмечић 2008: 14-20, 23-24.
} 
свим областима културе "13. Несумњиво, обнова патријаршије оставила је трага у свим могућим сферама црквеног, културног и друштвеног живота православних Срба, почев од административне структуре (успоставиле су се старе и постале нове епископије), архитектуре и градитељства (многи стари храмови су обновљени и саграђени нови, настале су нове манастирске целине од којих су најважнији овчарско-кабларски манастири груписани на подручју које се називало Малом Светом Гором), до иконографије (реновиране су биле старе уметничке реализације, сликале су се нове фреске и иконе нпр. у Студеници, Грачаници, Морачи, Крупи, Пећи, Дечанима и другим манастирима; радили су тада истакнути уметници - сликари нпр. Лонгин Зограф, Теофан Митрофановић и други), и књижевности (стално су се развијале велике књижевне врсте као што су хагиографија и химнографија, о чему сведоче нпр. Пајсијеви и други текстови; настала су историографска и епистолографска дела; непрестано су се преписивали и писали рукописи и рукописне књиге).

У закључку треба нагласити да је захваљујући обновљеној Пећкој патријаршији српска култура под турском окупацијом, у перманентној опасности и дефанзиви, испољила управо изузетан реконструкцијски и митомоторички потенцијал. Она се показала као непроменљива структура, доста трајна због дубоког и стабилног односа према прошлости, а пре свега због високе способности за селекцију, реконструкцију и актуализацију елемената који су јасни знаци српског идентитета и припадности. Реконструкција и актуализација прошлости показују потенцијал памћења ондашње српске културе која је постојала и функционисала као структура сачувана и трајна. У великој мери, захваљујући управо Цркви, српска култура је до краја 17, а и почетка или бар половине 18. века још увек функционисала у границама старог, традиционалног обрасца - модела од којега није одступала како у генолошком, тако у идејном и идеолошком погледу. Штавише, у доба обнове патријаршије она је испољила изванредну трајност и потенцијал креације, што категорички пориче одавно понављано мишљење о њеном схематизму, формално-идејној крутости, бедном вегетирању и сл. У то време она је средњовековни систем који се још стално развијао и који је био способан за конзервирање старих и стварање нових идеја, топоса, конструкција и концепта, а пре свега за то да служи као носилац заједничких, друштвених представа, имагинација, као медијум традиција које су формирале идентитет српске духовно-културне нације.

Дакле, у знаку Пећке патријаршије стара српска култура испољила је изузетан реконструкцијски, реорганизацијски, а пре свега митомоторички потенцијал, па се може и рећи да је под окриљем Цркве културни модел издржао пробу времена. У овом светлу још једном треба да се подвуче дуготрајност старог српског културно-друштвеног модела, његов развитак и

13 У том контексту користи се и назив - „доба друге патријаршије” види нпр. Ковачевић 1969: 175 .

${ }_{14}$ Види нпр. Суботин-Голубовић 1999: 48; Тричковић, 1980; Деретић 2005: 128; Дероко 1953: 298-299; Петковић 1969: 192-196; Петковић 1965: 237-251; Јевтић 1987: 33, 55. 
постојање у двема фазама које су биле пре свега детерминисане историјским, политичким и еклезијалним догађајима. Као што је већ речено, овај први период може се назвати стварним, када се уопште културни модел формирао и када је реч о стратегији фундирајућег овековечавања традиције. Он би трајао све до пада српске деспотовине. Међутим, овај други - од обнове Пећке патријаршије - може се именовати симболичним или просто меморијалним када се културни модел јавља већ као обавезна полазна тачка, када подлеже перманентној реконструкцији, актуализацији, кодификацији и локацији у регистру културног памћења.

\section{ЛИТЕРАТУРА}

Асман 2002: А. Асман, Рад на националном памћењу, Београд.

Битоски 1978: К. Битоски (ред.), Охридската Архиепископија. Охрид и Охридско низ историјата, кн. 2, Скопје.

Веселиновић 1937: Р. Веселиновић, Стање српске Цркве од пада српских држава под турску управу до обновљења под патријархом Макаријем, „Богословље”, год. ХІІ , св. 3-4, Београд.

Веселиновић 2004: Р. Веселиновић, Историја Српске православне иркве са народном историјом I (1219-1766), Београд.

Грујић 1989: Р. Грујић, Православна српска ирква, Крагујевац.

Деретић 2005: Ј. Деретић, Културна историја Срба. Предавања, Београд.

Дероко 1953: А. Дероко, Монументална и декоративна архитектура у средњовековној Србији, Београд.

Дучић 2008: Н. Дучић, Историја српске православне иркве, Гацко - Београд.

Екмечић 2008: М. Екмечић, Дуго кретање између клања и орања. Историја Срба у новом веку (1492-1992), 2 изд, Београд.

Зеремски 1920: И. Зеремски, Српска патријаршија од 1557-1592, Гласник Српске православне патријаршије 17.

Јевтић 1987: А. Јевтић (прир.), Задужбине Косова. Споменици и знамења Српског народа, Призрен-Београд.

Кашић 1969: Д. Кашић, Српска ирква под Турциима, у: Српска православна ирква 1219-1969. Споменица о 750-годишњищи аутокефалности, Београд.

Ковачевић 1969: Б. Ковачевић, Црква и књига последюих пет векова, у: Српска православна ирква 1219-1969. Споменииа о 750-годишњиции аутокефалности, Београд.

Леви-Строс 1989: К. Леви-Строс, Структурална антропологија, Загреб.

Мирковић 1965: М. Мирковић, Правни положај и карактер Српске иркве под турском влашћу (1459-1766), Београд.

Новаковић 1906: С. Новаковић, Туркско изарство пред српски устанак, Београд.

Петковић 1965: С. Петковић, Зограф Георгије Митрофановић у Пећкој патријариији 1619-1620, Гласник музеја Косова и Метохије, IX. Приштина. 
Петковић 1969: С. Петковић, Сликарство на подручију Пећке патријаршије од средине XV века до 1690. године, у: Српска православна ирква 1219-1969. Споменица о 750-годишьици аутокефалности, Београд.

Пузовић 2000: П. Пузовић, Српска црква од Светога Саве до укидања Пећке патријаршије 1766. године, у: Српска православна ирква. Прилози за историју, 2, Београд.

Пурковић 1976: М. Пурковић, Српски патријарси средюега века, Диселдорф.

Радонић 1950: Ј. Радонић, Римска курија и јужнословенске земље, Београд.

Руварац 1868: И. Руварац, О каталозима пећских патриараха, Гласник Српског ученог друштва, књ. VI, св. XXIII.

Руварац 1904: Д. Руварац, О укинућу пећске патријариије и юеном наслеђу, Сремски Карловци.

Слијепчевић 1933: Ђ. Слијепчевић, Пајсије. Архиепископ пећки и патријарх српски као јерарх и књижевни радник, „Богословље”, VIII, Београд.

Слијепчевић 1938: Ђ. Слијепчевић, Укидање пећке патријаршије 1766, „Богословље", ХІІІ, Београд.

Слијепчевић 1991: Ђ. Слијепчевић, Историја Српске православне иркве I, Београд.

Станојевић 1993/1926: С. Станојевић, Историја српског народа, 3 изд., Београд.

Стојановић 1923: Љ. Стојановић, Српска ирква од Арсенија II до Макарија, Глас Српске Краљевске Академије, књ. CVI, Београд.

Стојановић 1902: Љ. Стојановић, Стари српски записи и натписи, Зборник за историју, језик и књижевност српског народа, књ. I, Београд.

Стојановић 1903: Љ. Стојановић, Стари српски записи и натписи, Зборник за историју, језик и књижевност српског народа, књ. II, Београд.

Стојановић 1923: Љ. Стојановић, Стари српски записи и натписи, Зборник за историју, језик и књижевност српског народа, књ. IV, Сремски Карловци.

Суботин-Голубовић 1999: Т. Суботин-Голубовић, Српско рукописно наслеђе од 1557. године до средине XVII века, Посебна издања CAHУ књ. DCXL, Одељење језика и књижевности књ. 51, Београд.

Тричковић 1980: Р. Тричковић, Српска ирква средином XVII века, Глас САНУ СССХХ, Одељење историјских наука, књ. 2, Београд.

Ћирковић, Михаљчић 1999: С. Ћирковић, Р. Михаљчић (прир.), Лексикон српског средњег века, Београд.

Ћоровић 1929: В. Ћоровић, Мехмед-паша Соколовић, у: Народна енциклопедија СXC, књ. IV, Загреб.

Чубриловић 1960: В. Чубриловић, Српска православна црква под Турцима од $X V$ до XIX века, Зборник Филозофског Факултета, књ. V-1, Београд.

Asman 2011: J. Asman, Kultura pamćenja. Pismo, sećanje i politički identitet $u$ ranim visokim kulturama, Beograd.

Balandier 1984: G. Balandier, Anthropologie politique, Paris.

Balandier 1988: G. Balandier, Le désorde. Éloge du mouvment. Paris. 
Czykwin, Kierdelewicz 2010: E. Czykwin, H. Kierdelewicz (ред.), O naszym Prawostawiu (Przeglad Prawosławny - wybór tekstów 1985-2010), Białystok.

Gil 2005: D. Gil, Prawostawie. Historia. Naród. Miejsce kultury duchowej w serbskiej tradycji $i$ wspótczesności, Kraków.

Harvieu-Léger 1993: D. Harvieu-Léger, La religion pour mémoire, Paris.

Harvieu-Léger 1999: D. Harvieu-Léger, Religia jako pamięć, прев. M. Bielawska, Kraków.

Kula 2004: M. Kula, Między przeszłościq a przyszłościq. O pamięci, zapominaniu i przewidywaniu.

Lis-Wielgosz 2013: I. Lis-Wielgosz, O trwałości znaczeń. Siedemnastowieczna literatura serbska w stużbie tradycji, Poznań.

Meyendorff 1989: J. Meyendorff, Imperial Unity and Christian Divisions: The Church 450-680 A.D. (The Church in History), Crestwood.

Naumow 1998: A. Naumow, Berło innowiercy, y: Obraz kapłana, wodza, króla w kulturach stowiańskich, ред. T. Dąbek-Wirgowa, A. Z. Makowiecki, Warszawa.

Pfeilschifter 1913: G. Pfeilschifter, Die Balkanfrage in der Kirchengeschichte, München.

Piaget 1968: J. Piaget, Le structuralisme, Paris.

Papadakis 1999: A. Papadakis, Zarys dziejów Kościoła prawosławnego, y: Prawosławie. Światło wiary $i$ zdrój doświadczenia, ред. K. i J. Leśniewscy, Lublin.

Posern-Zieliński 2003: A. Posern-Zieliński (ред.), Etniczność a religia, Poznań.

Smith 2009: A. Smith, Ethno-symbolism and Nationalism. A Cultural Approach, New York.

Sorokin 1937: P. Sorokin, Social and Cultural Dynamics, New York.

Izabela Lis-Wielgosz

UNDER THE SIGN OF THE RENEWED PATRIARCHY IN PEĆ.
A FEW WORDS ABOUT OLD SERBIAN CULTURE

(Summary)

In the article, a problem of the renewed Patriarchy in Peć is discussed not so much from the historical and ecclesial perspective, but rather from the cultural and social point of view what makes it a multidimensional phenomenon which might be conceived especially as a consistent and unique project established in the service of Serbian tradition in order to maintain it in its unchanged medieval form. Due to this, the most essential features of the commented phenomenon are exposed as well as a model of functioning of Serbian Orthodox Church - initially as the archibishopric and next as the patriarchy along with its influence on historical, political, ecclesial, cultural and social reality in the period of Turkish occupation. The renewed patriarchy's contribution in the work of intensification of Serbian historical consciousness and in the codification of cultural memory is also emphasized to illuminate its extra-ordinary commitment to the forming of the genuine profile of literature and arts. What is more, a special potential of the aforementioned ideal and ideological carriers is highlighted in order to accentuate their ability to selection, reconstruction, reorganization and actualization of those cultural compo- 
nents which might be called identification and affiliation marks constructing peculiar signatures of the cultural system. In the article, a problem of memorial dimension of the Old Serbian culture, including its commemorative function related to the processes of heroization and sacralisation, has been discussed. The cultural model in question has been analysed from the perspective of memory discourse, and due to categories of places and figures of memory. The specificity of this cultural system has been explored in the context of uniqueness, durability and traditionalism. The literary, iconographic and architectural exemplifications, evoked in the article, which are to testify mytho- and mnemonic-motoric ability of the Old Serbian culture, are merely a modest representation of this phenomenon along with its memorial multidimensionality. 